\title{
IMPLEMENTASI VIDEO INFOGRAFIS TATA CARA PENDAFTARAN (STUDI KASUS KAMPUS PUSAT PMB UNIVERSITAS BUDI LUHUR)
}

\author{
Annisa Nur Madinah ${ }^{1)}$, Mohamad Salman Alfarisi ${ }^{2)}$ \\ ${ }^{1}$ Manajemen Informatika, Fakultas Teknologi Informasi, Universitas Budi Luhur \\ ${ }^{1,2} \mathrm{Jl}$. Raya Ciledug, Petukangan Utara, Kebayoran Lama, Jakarta Selatan 12260 \\ E-mail : madinahannisa@gmail.com ${ }^{1)}$, salman.alfarisi@budiluhur.ac.id ${ }^{2)}$
}

\begin{abstract}
Abstrak
Pembuatan video infografis bertujuan agar media informasi dan promosi pada Penerimaan Mahasiswa Baru (PMB) di Universitas Budi Luhur memanfaatkan penggunaan teknologi. Pada Penerimaan Mahasiswa Baru $(P M B)$ belum diterapkannya media informasi dan promosi berbasis teknologi, yang menjelaskan tata cara pendaftaran berbentuk video infografis. Penelitian ini menggunakan metode wawancara dengan karyawan Penerimaan Mahasiswa Baru (PMB), observasi calon pendaftar dan studi pustaka pada buku, jurnal serta literatur terkait penelitian sebagai bahan referensi. Dalam membuat video infografis ini, menggunakan gabungan dari berbagai media, seperti, tulisan, gambar, dan suara yang dikemas menggunakan software Adobe After Effects CS6 sehingga menghasilkan sebuah video. Hasil dari penelitian ini adalah terciptanya video infografis tata cara pendaftaran dalam bentuk format mp4 dan dapat disebarluaskan secara online melalui website Penerimaan Mahasiswa Baru (PMB) dan media sosial Universitas Budi Luhur.
\end{abstract}

Kata kunci: Video, Infografis, Pendaftaran

\section{PENDAHULUAN}

Modernisasi teknologi terus berkembang dan cepatnya informasi yang didapatkan setiap orang adalah hal yang biasa ditemui. Dengan mudahnya mendapat informasi, semakin mengefesienkan waktu. Untuk itu, manusia akan mencari alternatif agar mendapatkan informasi yang mudah dipahami dan mudah diakses. Infografis merupakan sebuah konsep umum penyajian informasi yang dalam penerapannya didasari oleh kreatifitas, keindahan (daya tarik), ketepatan isi dengan ilustrasi, serta keefektifan waktu yang diperlukan dalam menginterpretasikan informasi.[1].

Media informasi pada Penerimaan Mahasiswa Baru (PMB) Universitas Budi Luhur belumlah maksimal, saat ini hanya tersedia brosur untuk media informasi mengenai pendaftaran dan hal tersebut tidak mencakup semua informasi pendaftaran, sehingga hal tersebut kurang efektif. Penerimaan Mahasiswa Baru (PMB) Universitas Budi Luhur mempunyai website sendiri, namun, informasi yang ada di website tersebut sama dengan media informasi cetak yang disediakan oleh bagian Penerimaan Mahasiswa Baru (PMB) perbedaanya hanya berbentuk softcopy, dan jika pun ada informasi lain, bentuk informasinya hanya menggunakan teks.

Berdasarkan penjelasan diatas, dapat dirumusakan suatu permasalahan pada Penerimaan Mahasiswa Baru (PMB) yaitu, belum diterapkannya media informasi dengan tampilan yang menarik dan mudah dipahami, yang dapat digunakan sekaligus sebagai media promosi, dalam penelitian ini penulis membuat video infografis tata cara pendaftaran yang akan ditampilkan di website Penerimaan Mahasiswa Baru (PMB) maupun di media sosial Universitas Budi Luhur, video infografis yang dibuat tersebut termasuk dalam jenis infografis animasi.

Infografis Animasi (animated infographics) adalah jenis infografis dengan menggunakan media audio visual seperti televisi dan saluran video dalam jaringan seperti kanal Youtube dan Vimeo. Infografis animasi bisa disajikan dalam bentuk 2 dimensi (2D) maupun bentuk 3 dimensi (3D) dengan tampilan lebih kompleks. Konsep infografis animasi merupakan perpaduan antara elemen visual bergerak (motion) dan elemen audio.[2].

Tujuan dari penelitian Tugas Akhir ini yaitu untuk menerapkan video infografis tata cara pendaftaran pada website Penerimaan Mahasiswa Baru (PMB) maupun di media sosial Universitas Budi Luhur supaya informasi yang tersedia beragam, menarik dan mudah dipahami.

\section{METODE PENELITIAN}

Dalam penelitian ini, penulis menggunakan beberapa metode yang meliputi:

a) Metode Wawancara

Dilakukan untuk mendapat informasi secara langsung dengan cara tanya jawab kepada karyawan Penerimaan Mahasiswa Baru (PMB).

b) Metode Observasi

Dilakukan guna melihat perilaku calon pendaftar pada media sosial Universitas Budi Luhur yang menanyakan tentang pendaftaran. 
c) Studi Pustaka

Dilakukan dengan mengumpulkan data melalui buku, literatur dan jurnal sebagai sumber bacaan dan referensi terkait penelitian.

\subsection{Objek Penelitian}

Penerimaan Mahasiswa Baru (PMB) belum mempunyai media informasi berbentuk video infografis sebagai media informasi dan promosi sehingga penulis mengajukan pembuatan video infografis. Penulis merancang, membuat tampilan video dan menggabungkan berbagai elemen-elemen desain grafis menggunakan software Adobe After Effects CS6 supaya menghasilkan sebuah video.

\subsection{Analisa Objek}

Karena objek yang diteliti belum ada, maka Penerimaan Mahasiswa Baru (PMB) belum mempunyai media informasi berbentuk video infografis sebagai media informasi dan promosi sehingga penulis mengajukan pembuatan video infografis. Penulis merancang, membuat tampilan video dan menggabungkan berbagai elemen-elemen desain grafis menggunakan software Adobe After Effects CS6 supaya menghasilkan sebuah video.

Hambatan yang dihadapi dalam pembuatan video infografis ini terletak pada belum adanya desain acuan video infografis sehingga penulis harus membuat format desain yang sesuai dengan tempat yang diteliti dengan mengikuti brand guideline Universitas Budi Luhur.

Penulis membuat merchandise berupa stiker menggunakan desain video infografis sebagai acuan dan stationary dalam bentuk kartu ucapan ulang tahun untuk karyawan Universitas Budi Luhur.

\subsection{Konsep Desain}

Pada konsep desain, penulis mendeskripsikan tujuan dan struktur alur project yang dibuat sebelum kegiatan dimulai, sasaran dan batasan yang dituju mengenai desain yang dibuat berdasarkan penyelesaian masalah, lalu penulis juga membuat merchandise dan stationary berdasarkan brand guideline Universitas Budi Luhur.

Tujuan dari penjelasan diatas adalah, penelitian ini membuat video infografis dengan tema pembahasan implementasi video infografis tata cara pendaftaran, merchandise yang dibuat adalah stiker, dan stationary yang dibuat adalah kartu ucapan ulang tahun.

\subsection{Rancangan Layar Video}

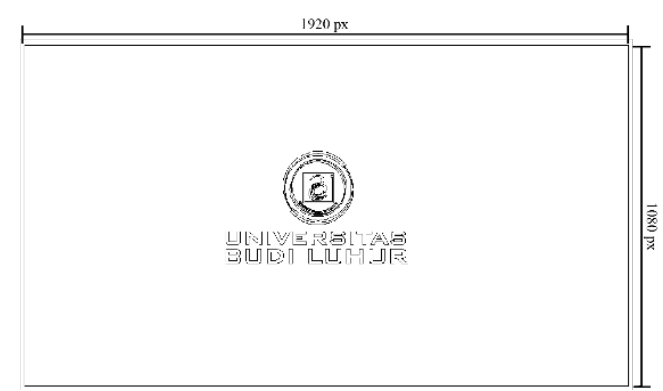

Gambar 1. Rancangan Layar Pop-up Logo

Pada gambar 1 menampilkan logo Universitas Budi Luhur saat opening

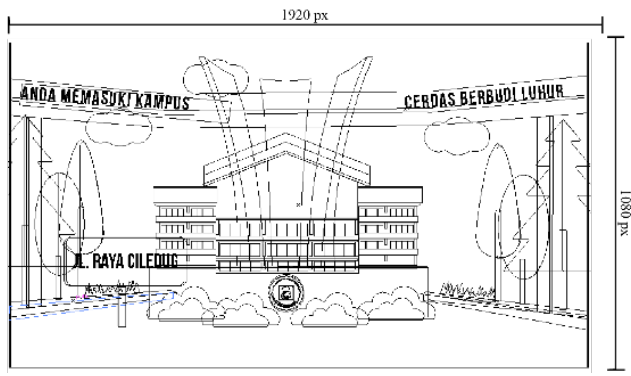

Gambar 2. Rancangan Layar Pengenalan UBL

Pada gambar 2 menampilkan penjelasan singkat Universitas Budi Luhur.

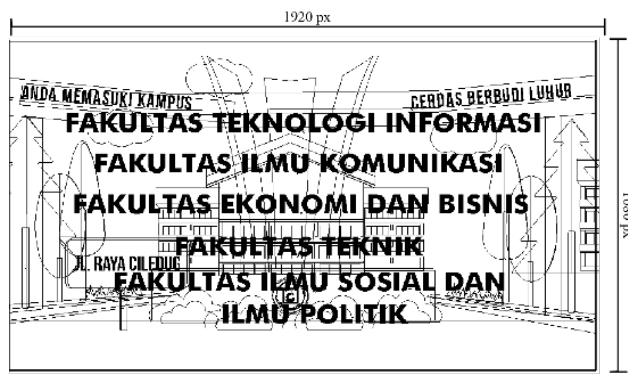

Gambar 3. Rancangan Layar Pengenalan Fakultas

Pada gambar 3 menampilkan pengenalan fakultas yang ada di Universitas Budi Luhur.

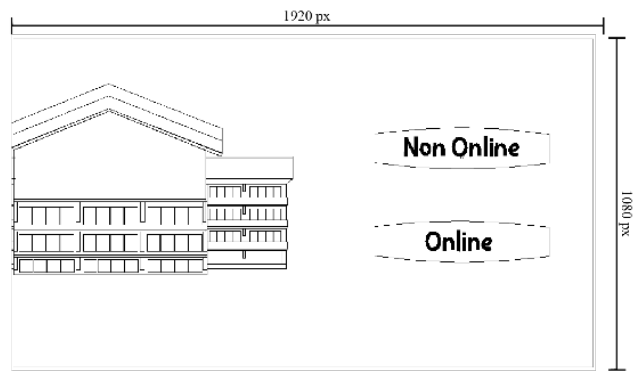

Gambar 4. Rancangan Layar Pilihan Cara Mendaftar 
Pada gambar 4 menampilkan pengenalan cara pendaftaran yang ada di Penerimaan Mahasiswa Baru (PMB) Universitas Budi Luhur

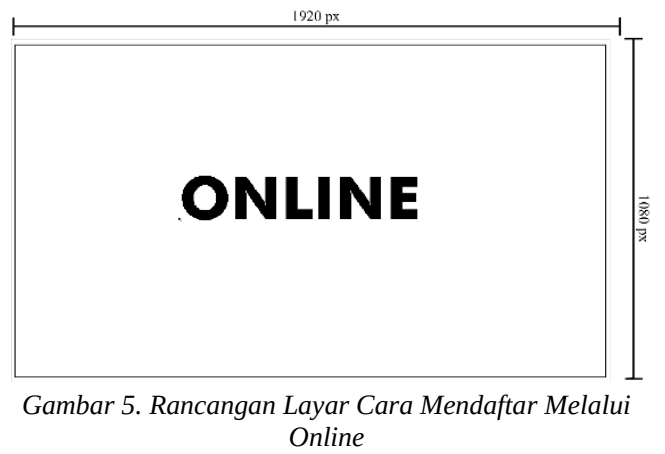

Pada gambar 5 menampilkan penjelasan langkah pendaftaran online pada website Penerimaan Mahasiswa Baru (PMB).

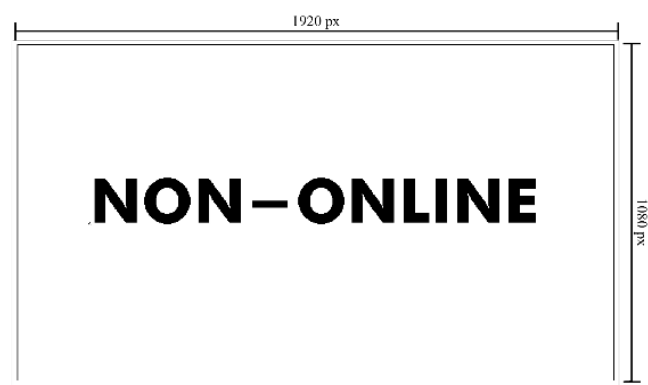

Gambar 6. Rancangan Layar Mendaftar Melalui NonOnline

Pada gambar 6 menampilkan penjelasan langkah cara pendaftaran non-online.

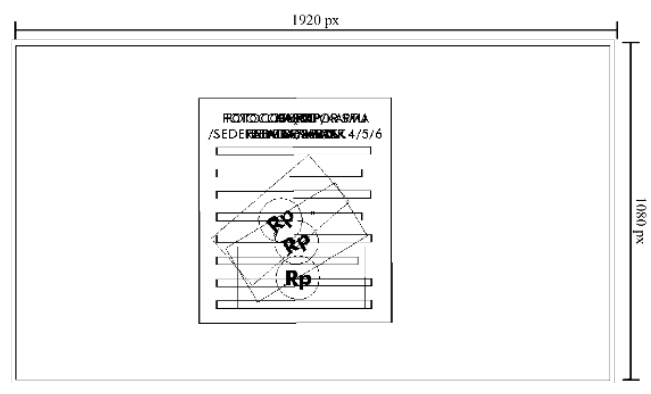

Gambar 7. Rancangan Layar Berkas Persyaratan Pendaftaran

Pada gambar 7 menampilkan penjelasan berkas yang harus dibawa saat melakukan pendaftaran.

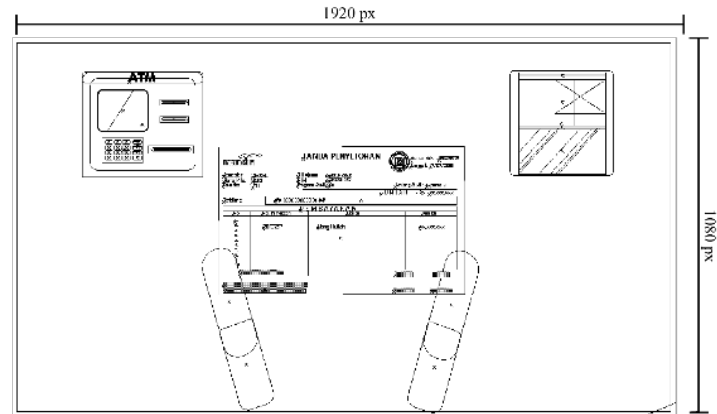

Gambar 8. Rancangan Layar Metode Pembayaran Biaya Kuliah

Pada gambar 8 menampilkan penjelasan metode pembayaran untuk melakukan pembayaran biaya kuliah.

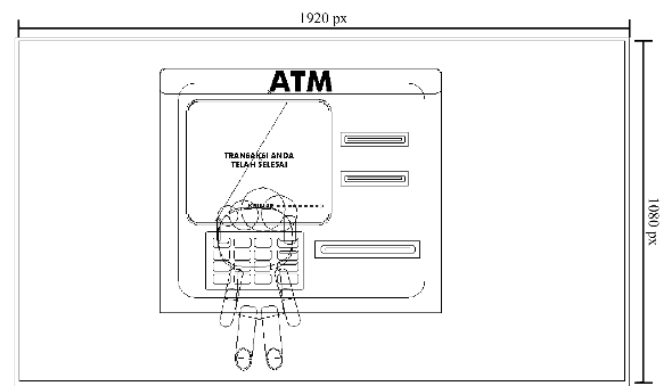

Gambar 9. Rancangan Layar Metode Pembayaran Melalu ATM

Pada gambar 9 menampilkan penjelasan langkah yang harus dilakukan saat melakukan pembayaran melalui ATM.

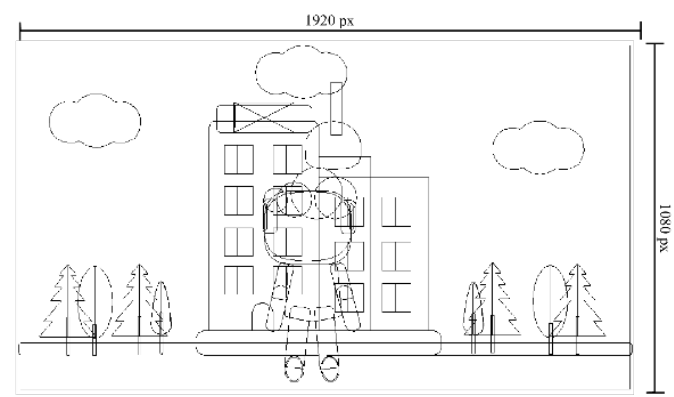

Gambar 10. Rancangan Layar Metode Pembayaran Melalu Teller

Pada gambar 10 menampilkan penjelasan langkah yang harus dilakukan saat melakukan pembayaran melalui Teller. 


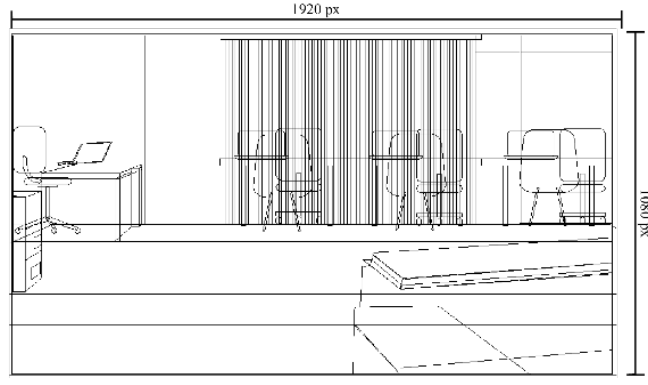

Gambar 11. Rancangan Layar Bagian Dalam Penerimaan Mahasiswa Baru

Pada gambar 11 menampilkan langkah konfirmasi pembayaran di Penerimaan Mahasiswa Baru (PMB).

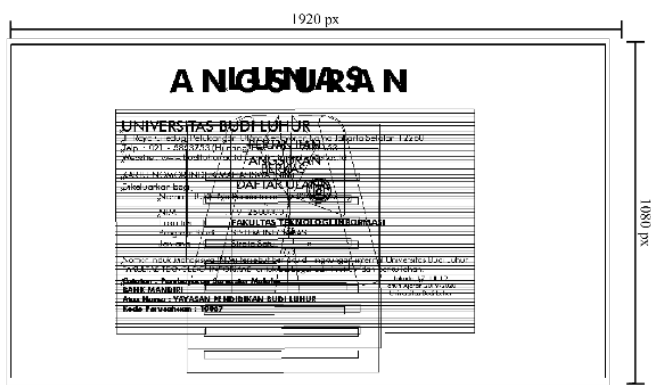

Gambar 12. Rancangan Layar Berkas yang Diterima

Pada gambar 12 menampilkan berkas yang didapat setelah melakukan konfirmasi pembayaran.

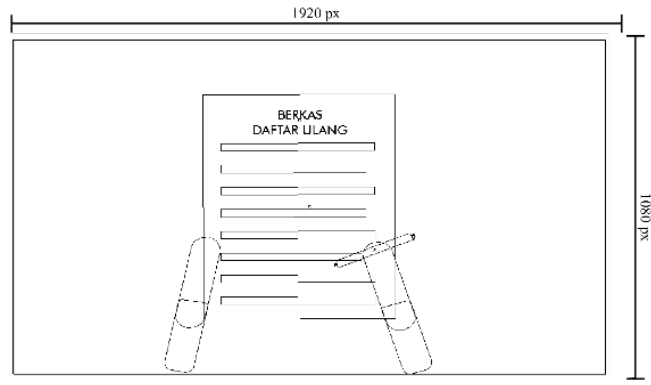

Gambar 13. Rancangan Layar Mengisi Berkas Daftar Ulang

Pada gambar 13 menampilkan penjelasan pengisian berkas daftar ulang.

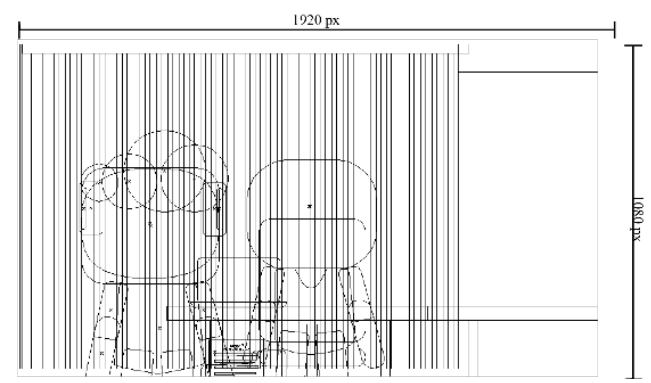

Gambar 14. Rancangan Layar Menyerahkan Berkas Dafta Ulang
Pada gambar 14 menampilkan langkah penyerahan berkas daftar ulang di Penerimaan Mahasiswa Baru (PMB).

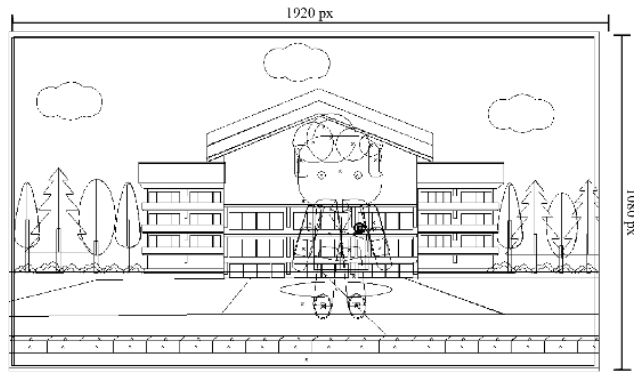

Gambar 15. Rancangan Layar Akhir Game

Pada gambar 15 menampilkan penjelasan saat proses pendaftar telah selesai.
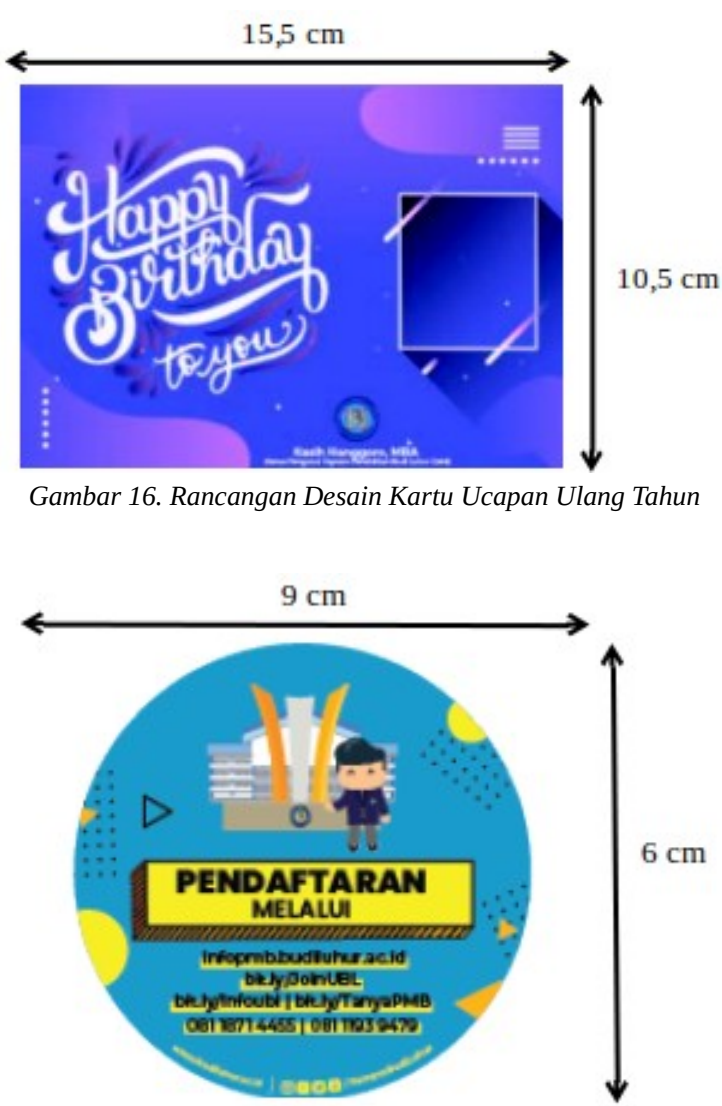

Gambar 17. Rancangan Desain Stiker 


\section{HASIL DAN PEMBAHASAN}

3.1. Tampilan Video

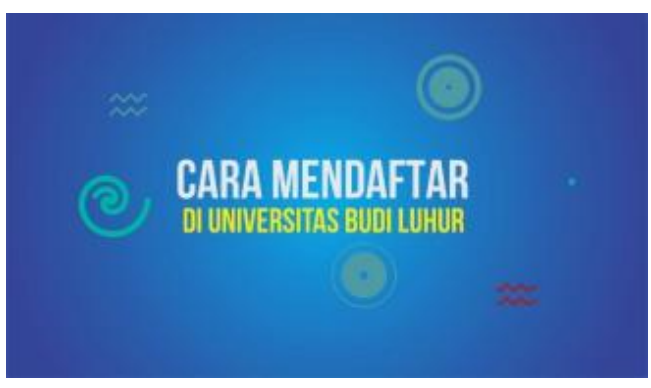

Gambar 18. Desain Intro

Pada gambar 18 menampilkan opening video infografis.

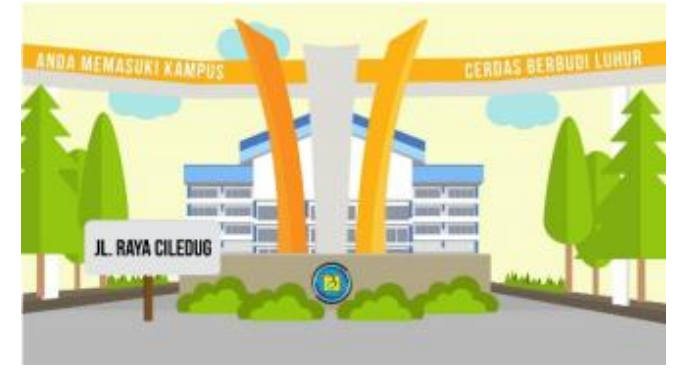

Gambar 19. Desain Pengenalan Universitas Budi Luhur

Pada gambar 19 menampilkan penjelasan singkat Universitas Budi Luhur.

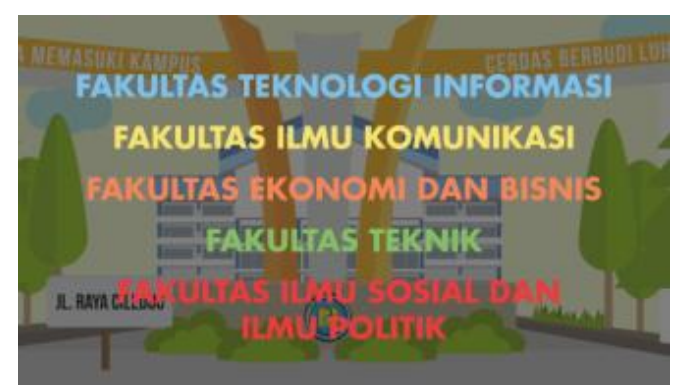

Gambar 20. Desain Pengenalan Fakultas

Pada gambar 20 menampilkan pengenalan fakultas yang ada di Universitas Budi Luhur.

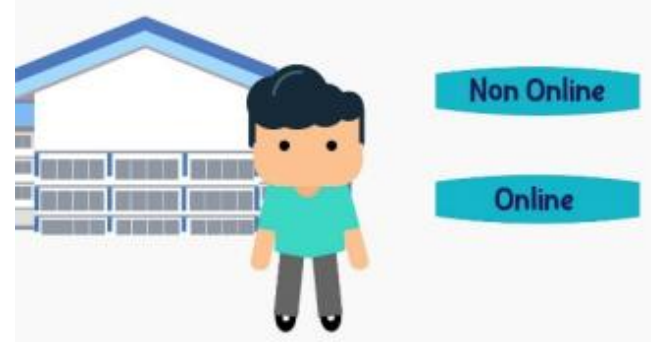

Gambar 21. Desain Pilihan Cara Mendaftar
Pada gambar 21 menampilkan pengenalan cara pendaftaran yang ada di Penerimaan Mahasiswa Baru (PMB) Universitas Budi Luhur.

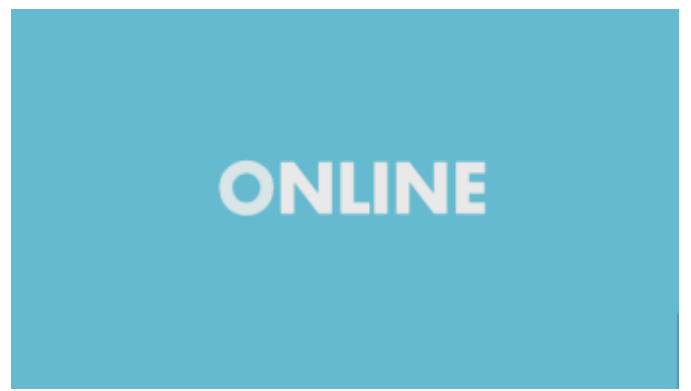

Gambar 22. Desain Cara Mendaftar Melalui Online

Pada gambar 22 menampilkan penjelasan langkah cara pendaftaran online pada website Penerimaan Mahasiswa Baru (PMB).

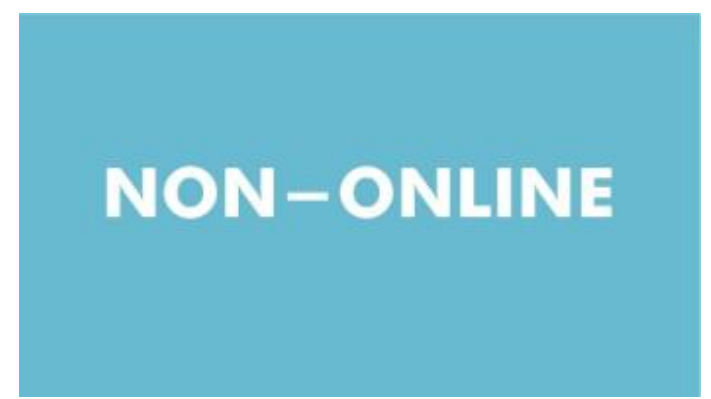

Gambar 23. Desain Mendaftar Melalui Non-Online

Pada gambar 23 menampilkan penjelasan langkah cara pendaftaran non-online.

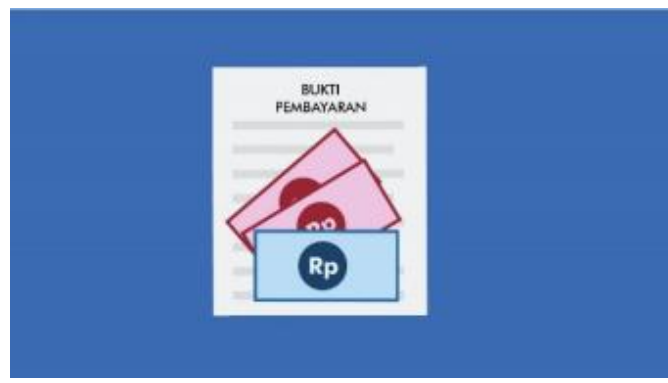

Gambar 24. Desain Berkas Persyaratan yang harus Dibawa

Pada gambar 24 menampilkan penjelasan berkas yang harus dibawa saat melakukan pendaftaran. 


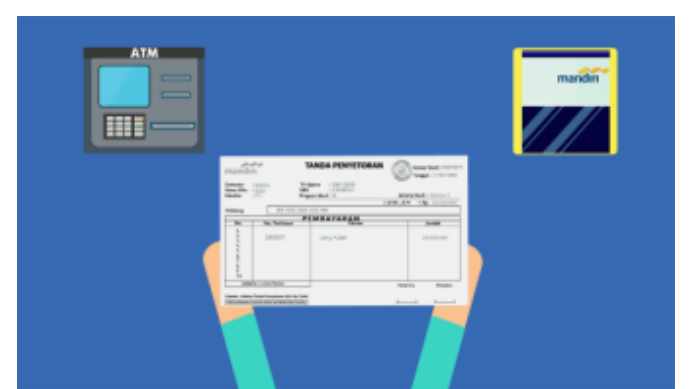

Gambar 25. Desain Metode Pembayaran Biaya Kuliah

Pada gambar 25 menampilkan penjelasan metode pembayaran untuk melakukan pembayaran biaya kuliah.

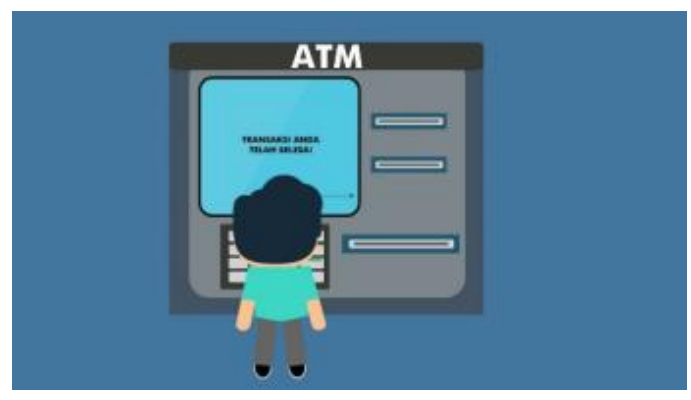

Gambar 26. Desain Metode Pembayaran Melalui ATM

Pada gambar 26 menampilkan penjelasan langkah yang harus dilakukan saat melakukan pembayaran melalui ATM.

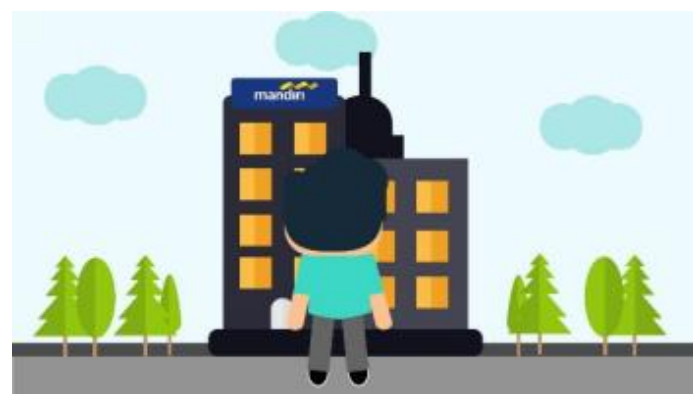

Gambar 27. Desain Metode Pembayaran Melalui Teller

Pada gambar 27 menampilkan penjelasan langkah yang harus dilakukan saat melakukan pembayaran melalui Teller.

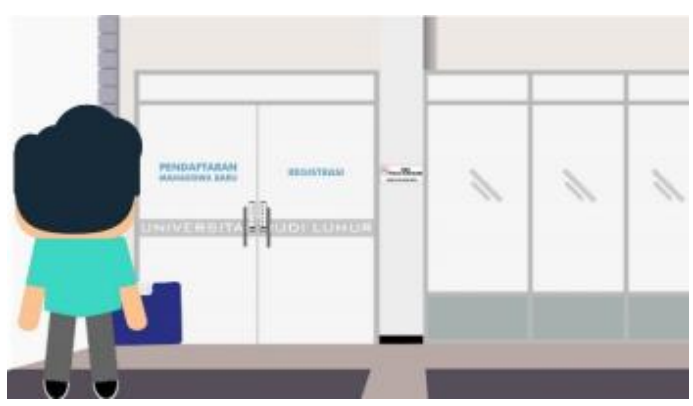

Gambar 28. Desain Datang ke Bagian Penerimaan Mahasiswa Baru untuk Konfirmasi Pembayaran
Pada gambar 28 menampilkan langkah konfirmasi pembayaran di Penerimaan Mahasiswa Baru (PMB).

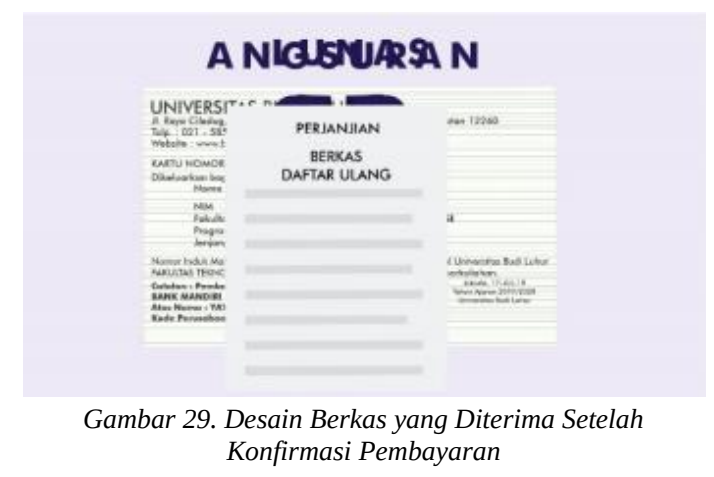

Pada gambar 29 menampilkan berkas yang didapat setelah melakukan konfirmasi pembayaran.

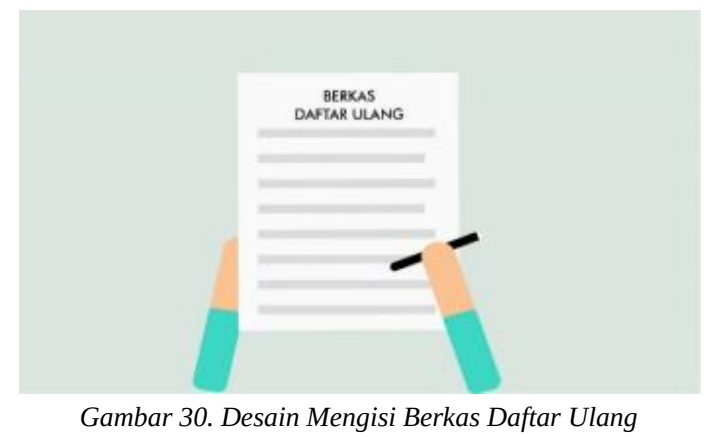

Pada gambar 30 menampilkan penjelasan pengisian berkas daftar ulang

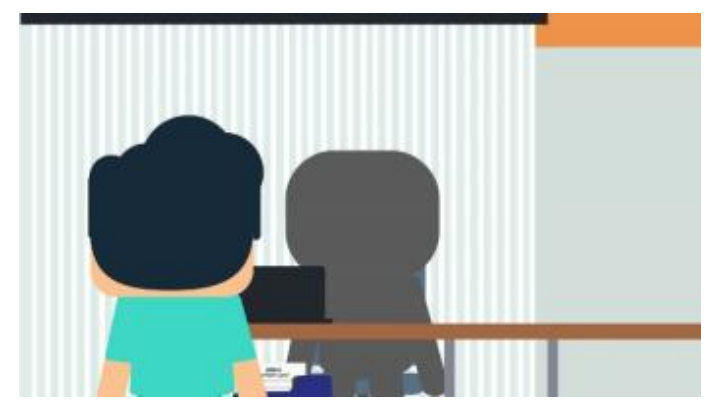

Gambar 31. Desain Menyerahkan Berkas Daftar Ulang

Pada gambar 31 menampilkan langkah penyerahan berkas daftar ulang di Penerimaan Mahasiswa Baru (PMB). 


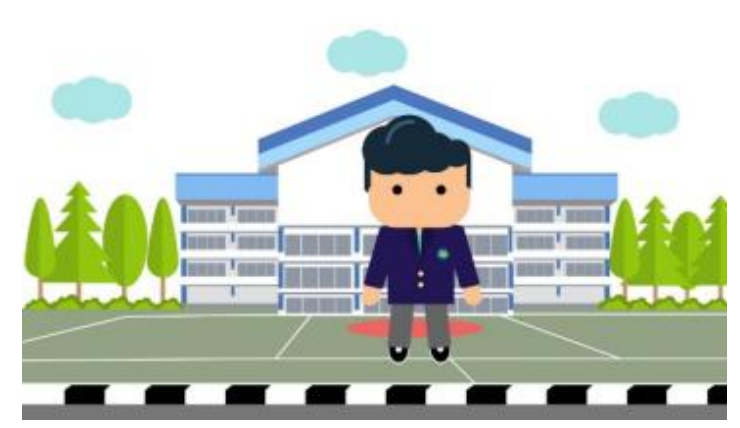

Gambar 32. Desain Proses Pendaftaran Selesai dan Telah Sah Menjadi Mahasiswa Universitas Budi Luhur

Pada gambar 32 menampilkan penjelasan saat proses pendaftar telah selesai.

\section{KESIMPULAN}

Berdasarkan hasil dari penelitian pada tugas akhir ini, dapat diambil kesimpulan bahwa, dalam pembuatan infografis yang dibuat menggunakan Adobe After Effects CS6 dapat memudahkan calon pendaftar untuk mengetahui tata cara pendaftaran, dan dapat menjadi media informasi dan promosi baru untuk PMB Universitas Budi Luhur agar meningkat kualitas informasinya. Dengan penjelasan yang menarik dan terstruktur, calon pendaftar dapat dengan mudah menyerap informasi yang diberikan dibanding hanya melihat informasi berbentuk teks saja. Adapun saran yang ditambahkan sebagai bahan pertimbangan dalam upaya pengembangan lebih lanjut, yaitu:

a. Bagi Universitas Budi Luhur, untuk memanfaatkan video infografis tata cara pendaftaran ini sebagai media informasi dan promosi.

b. Bagi Divisi PMB Universitas Budi Luhur, untuk membuat proses pendaftaran menjadi lebih singkat, dan praktis supaya selama prosesnya tidak perlu berulang kali datang ke Universitas Budi Luhur.

c. Bagi peneliti selanjutnya, sebaiknya menambahkan informasi tentang tata cara pendaftaran untuk jenjang S2, kelas karyawan, dan tata cara melalui jalur beasiswa sehingga informasi video infografis tata cara pendaftaran di Universitas Budi Luhur lengkap bukan hanya jalur reguler saja.

\section{DAFTAR PUSTAKA}

[1] Miftah, Rizal, \& Rully Khairul Anwar, "Pola Literasi Visual Infografer Dalam Pembuatan Informasi Grafis (Infografis),” Jurnal Kajian Informasi \& Perpustakaan, vol. 4, pp. 87, 2016.
[2] Lankow, J., Ritchie J., and Crooks Ross, Infografis: Kedahsyatan Cara Bercerita Visual, Jakarta, Gramedia Pustaka Utama, 2014. 